\title{
Fourth Congress of Illinois Society for Child-Study
}

\section{C. Van Liew}

To cite this article: C. C. Van Liew (1897) Fourth Congress of Illinois Society for Child-Study, The Pedagogical Seminary, 5:2, 293-299, DOI: 10.1080/08919402.1897.10534361

To link to this article: http://dx.doi.org/10.1080/08919402.1897.10534361

曲 Published online: 28 Aug 2012.

Submit your article to this journal 2

III Article views: 2

Q View related articles $\sqsubset$ 


\section{FOURTH CONGRESS OF ILIINOIS SOCIETY FOR CHIID-STUDY.}

The fourth annual congress of the Illinois Society for Child-Study was held April 28,-May I, I897. It was preceded April 26-28, by a series of conferences of child-study workers, chiefly representatives of educational interests in the States of the Mississippi valley, for the purpose of discussing the feasibilty and plan of a North American Child-Study Conference. As a result of these preliminary discussions such a conference was tentatively formed. The plan is the result of a very general call from a large number of States for co-operative effort on the part of State child-study societies, in securing especially an adequate educational recognition of the child-study movement. That representative men and women from the several States stand ready to unite in furthering the cause of child-study was abandantly proven by the large number present at the preliminary conference and by the large number of letters presented from those who could not be present.

Most prominent among the purposes of this conference, as thus far tentatively organized, are the furtherance of State Associations for childstudy, to secure the discussion of child-study problems in all fields that will be affected by child-study research, to furnish a central committee to direct the co-operative publication of such child-study literature as will best assist in the furtherance of the movement, especially along child-study lines. The organization provides for the formation of a so-called conference, to be composed of representatives from the State Child-Study Associations. The officers of the conference are to consist of a president, a vice-president, for each State represented in the conference, and a secretary-treasurer.

Dr. Wm. L. Bryan, of the University of Indiana, was elected president, and Dr. C. C. Van Liew, of the Illinois State Normal University, secretary-treasurer. The first regular meeting of the conference wili be held during the sessions of the N. E. A., when it is expected that the present tentative organization will be made permanent. It remains to be seen in the future whether or not there is a distinctive work that such an organization can perform. Probably the most striking feature of the plan is that which seeks the co-operation of the various States, each through a few of its best representatives, in the much needed work of effective and systematic propaganda and educational application.

The chief interest of the week centered in the sessions of the childstudy congress. Col. Francis W. Parker is the man to whom was due the credit of a very rich and attractive programme. The great success and large attendance at the congress the previous year, May, 1896, together with the unusually strong programme then presented, made it a matter of doubt as to whether as great a congress could be had in 1897. Mr. Parker, however, was fully equal to the task of eclipsing his former effort. The programme offered unusual attractions and was carried out with but two or three serious omissions, due to the unexpected inability of a few to be present. . . . It is the further purpose of this article to reproduce in brief some of the thoughts that were prominent at this congress, though it will be impossible to mention all the excellent papers and addresses. 
It was not one of the least attractions during the week that delegates from a distance were enabled to visit and inspect the Chicago Normal School, and that special arrangements were made by its department of psychology, to illustrate the work of the school, especially in childstudy lines. Under the direction of Dr. Colin A. Scott, physiological and psychological tests, illustrating the general work of the school, were made upon children and reports were given of the results of certain studies. In addition to this the monthly Parents' Reception, of the Chicago Normal School, which has become a recognized force in Chicago, and an open faculty meeting of the same school, also gave visitors some opportunity to see whither the educational movenents of Chicago are tending.

Wednesday afternoon at the Normal School was devoted to the discussion of the formation of Mothers' Leagues and Round Tables.

Wednesday evening was devoted to the question of the relation of child-study to Sunday School work. Patterson Dubois, of Philadelphia, editor of the Sunday School Times, and Dr. Walter L. Hervey, President of 'The 'Teachers' College, N. Y., were both unable to be present, but the discussion was opened by Dr. C. A. Thurber, Dean of Morgan Park Academy, in a valuable and interesting paper on Children's Religious Notions and their Relation to Religious Training.

Dr. Thurber opened with a graphic characterization of the Great Teacher who, "set a child in the midst of a lot of grown folks and told them to become like the child," while "we set a grown person in the midst of a lot of children and tell them to become like him." He believed that the Sunday Schools at large have resting upon them one of the most vital of educational problems, but that, not ignoring the good already accomplished, they by no means begin to meet the demands of modern life, or modern knowledge of childhood. The Sunday School needs a great revival of interest from a new source. There is nothing about the nature of the Sunday School to prevent the use and application of every pedagogical law found serviceable in the day school, much less of the laws of child nature. "Every good result, every good method of child-study should be transferred to the Sunday School as quickly as possible that it may reap the full benefit of as good influences as there are going."

Possibly no line of individual child-study yields greater returns to religious instruction than that which seeks to know something of the child's social instincts and of his social environment. From the latter come the forces which determine very largely the source of the child's ethical and social ideals and motives. Again, the study of children's interests in literature and in nature, reveals many points of contact with the child's religious life. The study of the Contents of Children's Minds, by Dr. G.S. Hall, has shown us, also, how necessary it is for the work of instruction, wherever it is undertaken and whatever the subject, to be adapted to the individual world of thought and action in which the child has grown up. "A child's mind will profit by no other ideas than those it can assimilate. . . . Whatever theological notions are presented, therefore, must be, if they are to find a lodging place, naive and artless, simple and primitive, like the nature of the child. For anything smacking of the subtlety of doctrine he can have no real appreciation." The historical parts of the Bible should be taught for many years more as deeply interesting stories of ethical value, rather than as history and chronology. Many of the Bible maxims and sayings are unintelligible to children, because they presuppose experiences most of them have never had, $e . g$." " a virtuous woman is far above rubies." "Suppose the "elders of the Jews did build and prosper through the prophesying of Haggai the prophet and 
Zechariah the son of Iddo;' what is that to a little child who has no conception of space, time, organized society, or even of our commonest adult conventional ways of doing things." Dr. Thurber's paper closed with an appeal to religious teachers to get back to Christ in method as well as in thought. In the discussion that followed, among those taking part in the further elaboration of the question, were Mrs. Lamareaux, of Chicago, and Col. Parker.

Thursday morning the regular opening of the congress occurred in Schiller Theatre. Col. Parker presided, and the opening address was delivered by Supt. of City Schools of Chicago, A. G. Lane. After his words of welcome, Dr. Wm. L. Bryan, of the University of Indiana, was introduced to speak on some applications of child-study. The chief thought to which Dr. Bryan gave emphasis centered about some investigations which have recently been made at the University of Indiana, under his directions. (Comp. Studies in the Physiology and Psychology of the Telegraphic Language, Psych. Rev., Vol. IV, No. I.) Briefly stated, the law is that the learner of telegraphy does not progress steadily and at a fixed ratio in his ability to receive the messages of others, but by fits and starts, increasing in speed rapidly for a time, then remaining at a standstill, then lunging ahead again, and so on, thus passing as it were a series of alternate upward inclines and level plateaus. Many get discouraged in the early plateaus and get no further, - never become expert; others achieve the highest plateaus and are known as experts. The problem that now naturally suggests itself to the psychologist is, in how far can this same law be found to be true in the acquisition of other facilities, $e . g$., learning to speak the native or foreign tongues? The educator, too, is at once interested in the inquiry as to whether or not his own dealings with children nay not be affected by the law, if it have any universal validity. He asks, - Do children experience these plateaus of comparatively stationary activity, in which no progress is discernible? Do they occur, for example, regulary, in teaching reading ? In giving facility in the use of the multiflication tables? If so, how am $I$ to conduct myself most rationally toward the child? Can he at this time of no progress be permitted to relax his efforts and let time bring about what seems to be the involuntary organization? Or must he still persist in unremitting, hard, every-day work until the plateau is passed ? If the latter, how am I to carry his interest over the trial? Dr. Bryan gave no solution to these questions, but left them with the teachers for further watching and experiment. They are certainly among the most suggestive and stimulating problems that have been put before the teachers in this work.

Dr. Bryan gave way on the programme to Dr. Reuben Post Halleck, author of Psychology and Psychic Culture, and the Education of the Central Nervous System, Principal of the Male High School, in Louisville, $\mathrm{Ky}$. His address was on The Education of the Motor Centers, and was ably and well delivered. He proceeded from the proposition that in proportion as the various centers of the brain are given exercise and brought out, as it were, by being called into play, does the individual become symmetrically developed. Not only all the senses require this development to secure the best development of the brain, but the muscles, as well, must be called into play as universally as possible, in order to secure the complete awakening and development of the motor centers. The results of the modification of the brain from motor activity are no less pronounced in the development of the brain than those from seuse activity. Motor training must begin early; it is to the credit of the kindergarten that it gives emphasis to this side of the child's development. Hurthermore, motor develop- 
ment must go hand in hand with sense development. Motor promptings pass from sensory centers to motor cells. Out of the sensory-motor activity develops the idea-motor activity. The idea, the residuum of the old sensation that first prompted the action, now prompts the same action; thus all ideas may be regarded by the educator in the light of possible sources of action. For example, the motor element in literature should not be passed by by the teacher without being called into play in the process of interpretation; the same is true of history. In closing, Mr. Halleck called attention to certain phases of motor memory of significance to the teacher, and to the fact that only through movement is the motor side of the being primarily educated. This last thought, as he showed, carries with it far reaching and important educational considerations.

The second general session was held Friday forenoon, also in Schiller Theatre. Dr. W. O. Krohn, of the University of Illinois, opened with a vigorous and stirring address on the value of certain phases of Child-Study in the School-room. His central thought was the need of having regard for the conditions of fatigue under which many pupils are asked to work. He was especially earnest in tracing the connection between fatigue and cases of precocity and abnormality. Dr. Krohn also gave expression to some valuable thoughts on the connections between nutrition and the emotional and ideational life of school children.

He was followed by Dr. Colin A. Scott, on Morbid States in Childhood and Brain Hygiene. Dr. Scott gave a very valuable and interesting address. He impressed his hearers with some idea of the importance of studying these morbid states of children wherever they occur. In closing he gave a list of the symptoms of fatigue, which is so closely associated with many cases of mental abnormality in children, as follows : headache, morning tire and evening excitement, too great reaction, sleeplessness, losing weight or excessive fat, depression, exaltation, fears, hypogastric pains, itching of special parts, coldness or heat of special parts, numbness, lack of sensitiveness, cramp and paralysis, erethic heart, unreliable memory, impaired powers of sense discrimination (eyes, skin), yawning, and laziness.

Dr. Scott was followed by Prof. L. H. Galbreath, who read a very inspiring and valuable paper on Child-Study for Class Work. He entered a vigorous and thoughful plea for the systematization of work in child-study that shall directly subserve the ends for which the teacher daily pursues the active work of instruction. Perhaps the central problem from which such child-study for class work could depart is that of the vital connection between mind and body, a problem in which the teacher is always intimately concerned. "The teacher should be interested in the health and growth of both mind and body. He is to find and control the conditions that influence the normal development of either of these." Hence "the physical and spiritual forces which have played about the pupil from his earliest days onward, the influences that are now pouring into his young life determining the character, direction and rapidity of its flow and the energy already stored up in this stream of consciousness, are all of concern to the teacher as features and factors which he must discover in the individual, bear in mind, and utilize in his training and instruction for future power and wisdom. Such child-study for the class room must constitute an essential element in the conduct of the recitation. In no other way is adaptation of the work of instruction and of the imposition of tasks, to be secured for each individual child. In no other way can the individual conditions of apperception and of physical energy be met. Moreover the teacher must be able, not only to 
read the conditions of her work in the physical expressions and manifestations of the child, but also to see in the same the reflection of her own work upon the mind through the body. Never can we get away from this intimate connection between mind activity and the accompanying nervous functions. The teacher must be able, in each individual, to read the results of her work in terms of the latter as well as of the former. These were, perhaps, the central thoughts of the paper, which were most skillfully elaborated by the speaker. The paper also contained many suggestions as to how such a line of childstudy could be arranged and carried out

The two closing general sessions, Saturday forenoon and afternoon, were held respectively in Central Music Hall and the Women's Club Rooms. Very large and appreciative audiences were present. At each session the audience was favored by an address from Dr. G. Stanley Hall, who spoke on the Period of Adolescence, and on some of the Scientific Results of Child-Study, that are of pedagogical significance. It is almost needless to say, at least to those who are accustomed to Dr. Hall's charming power as a lecturer, who have already listened to his rich and suggestive lectures, that the audience drank in every word with the feeling that they were listening to a man who, by virtue of his method and its extensive application, has a right to speak with new, even revolutionary, views. One cannot but feel that it is doing the scientific laity a great deal of good to learn, as they have been doing in more recent years through the popularization of science, what it costs of effort and time and drudgery, to be able to put one's self in a position to speak with new light. This appreciation is now becoming the more apparent, that writers and lecturers, as does Dr. Hall, give their audiences some conception of the methods they employ to reach the results they present. Those who listened to Dr. Hail on this occasion had many of them heard him the year preceding, and had come again to get further help, light and inspiration. Probably nothing called out more emphatic expressions of appreciation during the entire congress, or did more to strengthen the faith in what childstudy is going to do for human education and hunan life, than the wonderful lecture on Adolescence. The readers of the PEDAGogicaI SAMINARY have had opportunity in its pages to gather many of these same thoughts on this and the other subject, so that we shall make no attempt here to epitomize the two addresses.

Some mention must also be made of the department meetings. Prominent among them was the Sunday School Department. In addition to the general session devoted to the pedagogy of the Sunday School already described, one session was held in the Immanuel Baptist Church. On this occásion the center of attraction was the paper presented by Prof. D. A. Kiehle, of the University of Minnesota, on Pedagogy in the Sunday School. The paper was well received and elicited an interesting discussion. The kindergartners held one session. The chief address was delivered by Miss Lacy Wheelock, of Boston, who was followed by Mrs. J. L. Hughes, of Toronto, Can., Mrs. B. Ellen Burke, of New York, and Misses Bertha Payne, Amalie Hofer and Nina C. Vanderwaiker, of Chicago. The addresses were interesting and profitable, and with one exception evidence of a healthy interest on the part of kindergarteners in the child-study movement. This exception seemed to the writer to appear in a tendency to dwell upon the points in which child-study has proven the infallibility of Froebel, even to the neglect of some questious of relationship of very vital importance to the child.

The department of philosophy of the University of Chicago furnished two programmes of very great value, especially to the practical 
teacher. The first of these was a syniposium on expert physical examination, including The Need of F s? nu vation and Supervision by Prin. Ida Mighell, Examination from the tandpoint of Ear and Throat, Dr. T. Melville Hardie, Examination $w 1$ h Reference to Physical Culture, Miss Kate Anderson, of the University of Chicago, Some aspects of Child-Development, Dr. W. S. Christopher, and Supervision from the Standpoint of Contagious Diseases, Dr. W. K. Jaques. With the exception of the ladies in the list just mentioned, those taking part on this programme are all prominent physicians of Chicago, who are interesting themselves in these questions, from the point of view of their specialities. This programme was presented Friday afternoon, in Kent Hall, of the University. The same evening, and in the same place, the second programme was given by the University. Two valuable papers were presented, one on the Child and his Environment, by Dr. Mead, and the other on Method in Child-Study, by Dr. S. F. MacLennan, both of the University of Chicago, department of philosophy. Dr. Dewey presided at both of these meetings. It is to him chiefly and to his interest in the cause, that the Illinois Society for Child-Study owes the hearty co-operation of the University of Chicago, whenever possible, in its congresses.

The Art Department held one session Friday afternoon. It was in the charge of Miss Josephine Locke, Supervisor of Drawing in the city of Chicago, whose interest in the child-study movement, especially in its bearings on the art development of the child, are well known, both through her recent articles in Arts for America, and in her still more recently published guides for tlie Chicago teachers, which represent the practical work of the schools of the city in the line of art. The chief papers on the programme were, Art and the Child, by Dr. G. H. Mead, of the University of Chicago; Children's Fears as Material for Expression and a Basis for Education in Art, by Dr. Colin A. Scott, of the Chicago Normal School; and Primary Art Education, by Geo. L. Schreiber, of the University Settlement. The discussion that followed these addresses was especially full of life and interest in this field which has already begun to yield so materially to the influence of child-study research.

The Mothers' Department held one session, but, unfortunately, all who were to take part on the programme, with one exception, were prevented from being present. The audience was very welf repaid for its trouble, however, by the excellent paper of Mrs. Ellen Burke, of New York, and the interesting discussion that followed. Mrs. Burke's paper treated of Children's Secrets. Her thoughts were presented from the mothers' and teachers' point of view and dwelt upon the need of supplying the child with opportunity for the healthfnl exercire of his instinct for secrets. The paper gave a most forcible argument for the need of close sympathy for and understanding of child life, in showing that the obligation is a moral one, since our very indifference (as in the case of secrets) may expose the child to temptations of our own creation, too strong and subtle for him to withstand.

For the first time in three years a new set of officers was elected, many of the former desiring to retire. Prof. L. H. Galbreath, of the Illinois State Normal Uuiversity, was elected president, Dr. S. F. Mac Lennan, of the University of Chicago, was elected secretary-treasurer, and C. A. Thurber, Dean of Morgan Park Academy, chairman of the executive committee. Later in the year both president and secretarytreasurer were forced to resign owing to withdrawal from the State.

On the whole the congress was a very enthusiastic and profitable affair. The membership of the society was very greatly increased and yet the sessions had been attended by a very great many of the older 
members. In no respect could the work be said to be lagging in the State that had made the pioneer effort at State organization in the movement. The writer of this report, for three years secretary-treasurer of the society, has, since the last congress, which marked the beginning of the society's fourth year, withdrawn from connection with the society to labor in another State, and hence hopes to be pardoned some reminiscent reflections on its past history and work. The spirit which brought about the formation of this society was one of reform in the school rather than of contribution to scientific data. To be sure its constitution provided fur the latter also; but after all it should be acknowledged that the desire to change that which violates the child's life in the school of the present was the predominant motive. This end the work of the society has kept pretty steadily in view. It had, indeed, few among its active members who can lay any claim to having made contributions to the fund of child-study materials. But it has many who believed in the righeousness of the movement, and who desired to give it practical assistance. It is largely through the early efforts of this society that the message of child-study came to be spread abroad over the entire State. Teachers were stimulated to study their own children in the school-room, mothers their children, and both ultimately to turn to the great field of child-study literature that could show them what has already been done to render child-life and growth more intelligible. To this end the publications of the society were issued. They reveal little of the work actually done by its members in the study of children, and that little is rather crude and of meagre value except as a stimulus to others. Their chief purpose was rather to furnish suggestions for observation, and articles for study. In these respects the publications contain very much that is of great value. Under the auspices of the society a large number of Round Tables have been formed, which have carried on the study of child-study literature, and in some cases have even grappled with small problems. Many mothers of the State, and a number of the women's clubs, have become interested in the work. There are also many schools in the State, where important changes bave been wrought in the curriculum and method, and especially in the physical environment of the child, due to the work of propaganda carried on by the society. Finally the society has helped to influence materially the work of professionally training teachers. But on the other hand, at no time has the society as a body despite the dreams of some, ever been brought to the pursuit of a single problem that might yield something of scientific value. It may safely be doubted if, indeed, this should ever be its province. It is a good thing to have served in bringing about about a more open and receptive attitude of mind on the part of many on all educational problems. It is a good thing to have helped many to see that these things still are problems. There is still very much work of this kind to be done, and in connection with efforts at securing the recognition of new needs, indicated by new truths, there is still a good field before the society

C. C. VaN LIEW. 